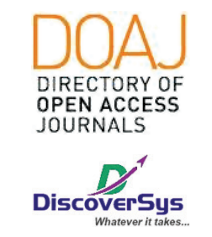

Published by DiscoverSys

\section{Pemeriksaan widal untuk mendiagnosis Salmonella typhi di Puskesmas Denpasar Timur 1}

\author{
Melania Antonia Barreto Cerqueira, ${ }^{1 *}$ Ni Nyoman Mahartini, ${ }^{2}$ \\ I Wayan Putu Sutirta Yasa ${ }^{2}$
}

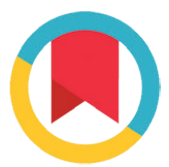

CrossMark

\title{
ABSTRACT
}

Introduction: Typhoid fever is an acute systemic infectious disease caused by Salmonella typhi which is still widely found in various developing countries, especially in the tropics and subtropics. Widal test is an agglutination reaction between antigen and $\mathrm{S}$. typhi 0 titer antibodies $>1 / 160$ and $\mathrm{S}$. typhi $\mathrm{H}$ titer $>1 / 160$, Aglutinin that is specific to Salmonella typhi in the serum of patients with typhoid fever.

Methods: This research was descriptive observational cross sectional. The population of the study was patients from the East Denpasar Health Center 1 who presented with clinical symptoms that supported.
Result: There were 10 sample (30\%) aged 0-10 years, 12 sample (36\%) people aged $11-20$ years, 7 sample (21\%) aged 21-30 years, and 4 sample (12\%) people aged $>30$ year. Samples with clinical symptoms of fever $>37^{\circ} \mathrm{C}$ with digestive disorders (nausea, vomiting, abdominal pain) with or without impaired consciousness were 18 samples (55\%). Samples with clinical symptoms offever $>37^{\circ} \mathrm{C}$ with digestive tract disorders were 11 samples (33\%). Samples with fever $>37^{\circ} \mathrm{C}$ were 4 samples (12\%)

Conclusion: There were $3 \%$ of positive widal test and $97 \%$ of negative widal test in the East Denpasar Health Center 1.

Key Words: Salmonella Typhi, Widal Test

Cite This Article: Cerqueira, M.A.B. Mahartini, N.N., Yasa, I.W.P.S. 2019. Pemeriksaan widal untuk mendiagnosis Salmonella typhi di Puskesmas Denpasar Timur 1. Intisari Sains Medis 10(3): 777-780. D0I: 10.15562/ism.v10i3.453

\section{ABSTRAK}

Latar Belakang: Demam tifoid merupakan suatu penyakit infeksi akut sistemik yang disebabkan oleh Salmonella typhi yang masih dijumpai secara luas di berbagai negara berkembang terutama di daerah tropis dan subtropics. Uji Widal adalah suatu reaksi aglutinasi antara antigen dan antibody $S$. typhi 0 titer $>1 / 160$ dan S. typhi $\mathrm{H}$ titer $>1 / 160$, Aglutinin yang spesifik terhadap Salmonella typhi terhadap dalam serum penderita demam tifoid.

Metode: Penelitian ini bersifat observasional cross sectional deskriptif Populasi Penelitian adalah pasien dari Puskesmas Denpasar Timur 1 datang dengan gejala klinis yang mendukung.
Hasil: Rentang usia dari 33 pasien subjek penelitian, terdapat 10 sampel(30\%) berusia 0 - 10 tahun, 12 sampel (36\%) sampel berusia 11 - 20 tahun, 7 sampel (21\%) berusia 21-30 tahun, dan 4 sampel (12 \%) sampel berusia $>30$ tahun. Sampel dengan gejala klinis demam $>37^{\circ} \mathrm{C}$ dengan gangguan pencernaan (mual, muntah, nyeri perut) dengan atau tanpa gangguan kesadaran sebanyak 18 sampel (55\%). Sampel dengan gejala klinis demam $>37^{\circ} \mathrm{C}$ dengan gangguan saluran pencernaan sebanyak 11 sampel (33\%). Sampel dengan demam $>37^{\circ} \mathrm{C}$ sebanyak 4 sampel (12\%)

Simpulan: Terdapat $3 \%$ sampel dengan widal positif dan $97 \%$ sampel dengan widal negatif di Puskesmas Denpasar Timur 1.
'Program Studi Pendidikan Dokter, Fakultas Kedokteran Universitas Udayana

2Departemen Patologi Klinik, Fakultas Kedokteran Universitas Udayana

\section{*Korespondensi:}

Melania Antonia Barreto Cerqueira, Program Studi Pendidikan Dokter, Fakultas Kedokteran Universitas Udayana melaniasequeira96@gmail.com

Diterima: 20-03-2019

Disetujui: 21-11-2019

Diterbitkan: 01-12-2019

Kata Kunci: Salmonella typhi, Uji Widal

Cite Pasal Ini: Cerqueira, M.A.B. Mahartini, N.N., Yasa, I.W.P.S. 2019. Pemeriksaan widal untuk mendiagnosis Salmonella typhi di Puskesmas Denpasar Timur 1. Intisari Sains Medis 10(3): 777-780. DOl: 10.15562/ism.v10i3.453

\section{PENDAHULUAN}

Demam tifoid merupakan suatu penyakit infeksi akut sistemik yang disebabkan oleh Salmonella typhi yang masih dijumpai secara luas di berbagai negara berkembang terutama di daerah tropis dan subtropiks. Gejala klinik dari Salmonella typhi demam > 37 celsius, gangguan pencernaan mual, muntah, nyeri perut, serta atau tanpa gangguan kesadaran. Penyakit ini juga merupakan masalah kesehatan masyarakat yang penting karena penyebarannya berkaitan erat dengan urbanisasi, kepadatan penduduk kesehatan lingkungan, sumber air dan sanitasi yang buruk serta standar higiene industri pengolahan makanan yang masih rendah. ${ }^{1,2}$

Menurut data WHO tahun 2003, diprediksikan sekitar 17 juta kasus demam tifoid di seluruh dunia dengan angka insiden 600.000 kasus kematian tiap 
tahun. Di Indonesia kasus demam tifoid masih merupakan penyakit endemik. Penyakit ini jarang ditemukan secara epidemik, lebih bersifat sporadik yang terpencar - pencar di suatu daerah. Frekuensi kejadian demam tifoid di Indonesia pada tahun 1990 sebesar 9,2 dan pada tahun 1994 terjadi peningkatan menjadi 15,4 per 10.000 penduduk. Insiden demam tifoid di Indonesia bervariasi di tiap daerah dan biasanya terkait dengan sanitasi lingkungan. Pada daerah pedesaan (Jawa Barat) insidennya sekitar 157 kasus per 100.000 penduduk, sedangkan di daerah perkotaan ditemukan 760-810 kasus per 100.000 penduduk per tahun. ${ }^{3}$

Umur penderita yang terkena di Indonesia dilaporkan antara 3-19 tahun pada 91\% kasus demam tifoid. Gejala-gejala klinis yang timbul sangat bervariasi dari ringan sampai berat yang disertai dengan komplikasi. Pada minggu pertama, keluhan dan gejala serupa dengan penyakit infeksi akut pada umumnya, yaitu demam nyeri kepala, pusing, nyeri otot, anoreksia, mual, munta, obstipasi dan atau diare, perasaan tidak enak di perut, batuk, dan epistaksis. Pada pemeriksaan fisik hanya di dapatkan peningkatan suhu badan. Dalam minggu keuda gejala-gejala menjadi lebih jelas berupa demam, bradiakardi relatif, lidah tifoid (kotor di tengah, tepi dan ujung merah serta tremor), hepatomegali, splenomegali, gangguan kesadaran berupa somnolen, stupor, koma, delirium, atau psikosis. ${ }^{4}$

Pemeriksaan laboratorium yang paling sering digunakan adalah uji serologis. Kultur salmonella merupakan gold standard dalam menegakkan diagnosis demam tifoid. Tes serologis lain yang dapat digunakan dalam menentukan diagnosis demam tifoid adalah tes Widal, dan tes IgM Salmonella typhi. Pada kultur darah, hasil biakan yang positif memastikan demam tifoid. Pada uji Widal, akan dilakukan pemeriksaan reaksi antara antibodi aglutinin dalam serum penderita yang telah mengalami pengenceran berbeda-beda terhadap antigen somatic $(\mathrm{O})$ dan flagela $(\mathrm{H})$ yang ditambahkan dalam jumlah yang sama sehingga terjadi aglutinasi. Pengenceran tertinggi yang masih menimbulkan aglutinasi menunjukaan titer anti bodi dalam serum. ${ }^{5}$

Prinsip tes Widal adalah pasien dengan demam tifoid atau demam enteric akan memiliki antibodi di dalam serumnya yang dapat bereaksi dan beraglutinasi dilusi ganda. Pada daerah endemis demam typhoid sering ditemukan level antibodi yang rendah pada populasi normal. Penentuan diagnosis yang tepat untuk hasil positif dapat menjadi sulit pada area yang berbeda. Oleh karena itu, penting untuk menetapkan level antibodi pada populasi normal di daerah atau area khusus supaya penentuan nilai ambang batas atas titer antibodi signifikan. Hal tersebut khususnya penting jika hanya ada sampel serum akut tanpa ada sampel serum periode convalescence untuk pengetesan Widal. ${ }^{6}$

\section{METODE}

Penelitian ini bertujuan untuk mengetahui karakteristik pemeriksaan Widal pada penderita Salmonella typhi, dengan keluhan demam $>37^{\circ} \mathrm{C}$, gangguan saluran pencernaan, mual muntah nyeri perut, serta atau tanpa gangguan kesadaraan di Puskesmas Denpasar Timur 1. Penelitian ini merupakan penelitian observasional cross sectional deskriptif. Penelitian dilaksanakan di di Puskemas Denpasar Timur 1 pada bulan November 2018.

Sampel penelitian ini adalah pasien yang datang mencari pelayanan kesehatan di puskesmas Denpasar Timur 1 yang memenuhi kriteria inklusi dan eksklusi. Kriteria inklusi adalah pasien dengan gejala klinis yang mendukung pada demam tifoid (demam $>37^{\circ} \mathrm{C}$ dengan gangguan saluran pencernaan seperti mual, muntah, nyeri perut serta atau tanpa gangguan kesadaraan. Pasien bersedia untuk dilakukan pemeriksaan Widal. Kriteria eksklusi adalah pasien yang memiliki gangguan imonologis atau mendapat terapi immunosupresan, pasien tidak bersedia untuk di dilakukan pemeriksaan Widal. Penelitian ini mengikutsertakan 33 sampel. Pengambilan sampel penelitian dilakukan dengan menggunakan teknik total sampling.

Penelitian ini menggunakan data primer dengan pemeriksaan Widal pada darah dari sample penelitian. Darah dari sampel penelitian diambil pada pembuluh darah vena, dimasukan ke dalam tabung kecil yang steril, kemudian dibawa ke laboratorium untuk dilakukan pemeriksaan. Analisis statistik dilakukan dengan bantuan piranti lunak SPSS 20 for Windows.

\section{HASIL}

Hasil penelitian pada tabel 1 memperlihatkan dari 33 pasien terdapat 10 sampel $(30 \%)$ berusia 1 10 tahun, 12 sampel (36\%) berusia 11-20 tahun, 7 sampel (21\%) berusia 21 - 30 tahun dan 4 sampel (12\%) sampel berusia lebih dari 30 tahun. Distribusi sampel berdasarkan jenis kelamin terdapat 15 sampel (45\%) laki-laki dan 18 sampel (55\%) perempuan.

Pasien yang datang berobat ke puskesmas Denpasar Timur 1 dan ikut dalam penelitian ini dengan gejala klinis demam $>37^{\circ} \mathrm{C}$ dengan gangguan pencernaan (mual, muntah, nyeri perut) dengan atau tanpa gangguan kesadaran sebanyak 18 sampel (55\%). Pasien dengan gejala klinis demam $>37^{\circ} \mathrm{C}$ dengan gangguan saluran 
Tabel 1 Karakteristik pasien bedasarkan umur dan jenis kelamin

\begin{tabular}{lcc}
\hline Karakteristik & (n) & (\%) \\
\hline Umur pasien (tahun) & & \\
0 - 10 tahun & 10 & 30 \\
$11-20$ tahun & 12 & 36 \\
$21-30$ tahun & 7 & 21 \\
Lebih dari 30 tahun & 4 & 12 \\
Jenis Kelamin & & \\
Laki-Laki & 15 & 45 \\
Perempuan & 18 & 55 \\
\hline
\end{tabular}

Tabel 2 Karakteristik pasien berdasarkan gejala klinis

\begin{tabular}{lll}
\hline Gejala Klinis & (n) & (\%) \\
\hline $\begin{array}{l}\text { 1. Demam }>37^{\circ} \mathrm{C} \text { dengan gangguan saluran } \\
\text { pencernaan (mual, muntah, nyeri perut) dengan } \\
\text { atau tanpa gangguan kesadaran. }\end{array}$ & 8 & 55 \\
$\begin{array}{l}\text { 2. Demam }>37^{\circ} \mathrm{C} \text { dengan gangguan saluran } \\
\text { pencernaan }\end{array}$ & 11 & 33 \\
3. Demam $>37^{\circ} \mathrm{C}$ & 4 & 12 \\
\hline
\end{tabular}

Tabel 3 Hasil pemeriksaan Uji Widal

\begin{tabular}{lcc}
\hline Hasil Pemeriksaan & (n) & (\%) \\
\hline Positif & 1 & 3 \\
Negatif & 32 & 97 \\
\hline
\end{tabular}

pencernaan sebanyak 11 sampel (33\%). Sedangkan yang hanya demam $>37^{\circ} \mathrm{C}$ saja sebanyak 4 sampel (12\%) (Tabel 2).

Terdapat 1 sampel (3\%) dengan Uji Widal positif dan 32 sampel (97\%) dengan Uji Widal negatif. Pasien dengan Uji Widal positif adalah anak anak berusia 9 tahun dengan gejala klinis demam $>37^{\circ} \mathrm{C}$ dengan gangguan pencernaan (mual, muntah, nyeri perut) dengan atau tanpa gangguan kesadaran (Tabel 3).

\section{PEMBAHASAN}

Dari penelitian ini didapatkan 1 sampel (3\%) dengan Uji Widal positif dan 32 sampel (97\%) dengan Uji Widal negatif. Berdasarkan petunjuk dari kit insent kriteria positif bila titer antibody $\mathrm{O}>1 / 160$ dan untuk titer antibody $\mathrm{H}>1 / 160$. Pemeriksaan dilakukan dengan mengambil serum sebanyak satu kali terhadap pasien. Pasien dipilih berdasarkan gejala klinis demam $>37^{\circ} \mathrm{C}$, dengan gangguan saluran pencernaan ( mual, muntah, nyeri perut) dengan atau tanpa gangguan kesadaran dan didapat 18 sampel (55\%). Pasien dengan gejala klinis demam $>37^{\circ} \mathrm{C}$, dengan gangguan pencernaan didapat 11 sampel (33\%). Sedangkan yang hanya demam $>37^{\circ} \mathrm{C}$ saja didapat 4 sampel (12\%).

Pada penelitian ini didapatkan jumlah pasien sebanyak 33 sampel, laki laki 15 sampel (45\%) dan perempuan sebanyak 18 sampel (55\%). Alat dan reagen yang digunakan dalam penelitian ini adalah reagen $\mathrm{S}$. typhi $\mathrm{O}$, reagen $\mathrm{S}$. typhi $\mathrm{H}$, micro pipet, slide hapus, kartu, rotator dan serum pasien. Pada penelitian ini terdapat 3 pasien dengan hasil Uji Widal S. typhi H dengan titer 1/320. Hasil Uji Widal seperti ini kemungkinannya adalah pasien pernah menderita infeksi Salmonella typhi dalam 6 bulan, sehingga IgG terhadap Salmonella typhi masih dapat di deteksi. ${ }^{3}$

Di Negara - negara Barat diamana infeksi Salmonella typhi sangat jarang maka bila terdapat hasil positif pada pengenceran kecil, sudah dikatakan hasil Uji Widal positif. Di Indonesia, diamana infeksi Salmonella typhi sering terjadi karena merupakan daerah endemis, maka sebaiknya hasil positif ditetapkan pada pengenceran besar (>1/160) agar tidak terjadi kelebihan diagnosis infeksi Salmonella typhi. Penetapan diagnosis infeksi Salmonella typhi berkaitan dengan penggunaan antibiotik untuk terapi. ${ }^{4}$

Widal merupakan salah satu teknik serologi untuk membantu dalam penegakan diagnosis demam tifoid. Pemeriksaan ini didasarkan dengan adanya antibodi aglutinin dalam serum pasien yang terinfeksi terhadap antigen $\mathrm{H}$ (flagel) dan $\mathrm{O}$ (somatik) bakteri, Salmonella typhi. Hasil positif pemeriksaan Widal dapat meningkatkan indeks kecurigaan adanya demam tifoid dengan titer aglutinin sebesar $\geq 1 / 320 .^{7,8}$

Hasil positif pemeriksaan Widal dapat disebabkan oleh karena berbagai macam hal, diantaranya pasien yang diperiksa memiliki indikasi infeksi demam tifoid akut atau pernah terinfeksi demam tifoid sebelumnya, imunisasi sebelumnya dengan antigen Salmonella, reaksi silang dengan Salmonella nontifoid, variabilitas dan standar antigen komersial yang kurang baik, infeksi malaria atau Enterobacteriaceae, dan penyakit lain seperti demam dengue Hasil negatif pemeriksaan Widal dapat disebabkan oleh tidak adanya infeksi oleh bakteri Salmonella typhi, karier, antigen bakteri yang tidak adekuat pada sel host untuk menginduksi terbentuknya antibodi, kesalahan pada saat pelaksanaan pemeriksaan, dan sudah mendapatkan terapi antibiotik sebelumnya. ${ }^{7}$

\section{SIMPULAN}

Terdapat 3\% sampel dengan widal positif dan 97\% sampel dengan widal negatif di Puskesmas Denpasar Timur 1. Banyak kelemahan dalam 
penulisan ini antara lain jumlah sampel yang sangat kurang, tempat penelitian terbatas pada satu fasilitas kesehatan, jenis parameter pemeriksaan terbatas sesuai dengan kesanggupan dana. Agar dapat mewakili populasi, jumlah sampel seharusnya ditambah dengan kriteria gejala klinis yang baik, meliputi beberapa fasilitas kesehatan dan menambah jumlah parameter laboratorium.

\section{KONFLIK KEPENTINGAN}

Penulis menyatakan tidak terdapat suatu konflik kepentingan terhadap publikasi dari artikel ini.

\section{PENDANAAN}

Penelitian ini tidak mendapatkan suatu pendanaan yang diberikan oleh pemerintah ataupun lembaga swasta lainnya.

\section{KONTRIBUSI PENULIS}

Konsep penelitian: Anggraini, Sari Wulan Dwi Sutanegara, Komang Andi Dwi Saputra. Pengumpulan data, input data dan pengolahan data: Anggraini. Penyusunan naskah Penelitian: Anggraini.

\section{ETHICAL CLEARANCE NUMBER}

1606/UN14.2.2/PD/KEP/2018.

\section{DAFTAR PUSTAKA}

1. Prasetyo RV., Ismoedijanto. Metode Diagnostik Demam Tifoid Pada Anak. FK UNAIR/RSU Dr. Soetomo. Surabaya. 2011. Tersedia: URL: http://www.pediatrik.com/ buletin/06224114418-f53zji.pdf. Diakses: 20 januari 2018.

2. Prayoga DK., Fatmawati ND. Identifikasi Salmonella spp pada feses penjamah makanan di rumah potong ayam RJ dengan metode kultur. Intisari Sains Medis. 2018. 9(3). DOI: 10.15562 /ism.v9i3.287.

3. World Health Organization. Diagnosisof typhoid fever. Background document:The diagnosis, treatment, and prevention of typhoid fever. 2003. Tersedia: URL: http:// whqlibdoc.who.int/hq/2003/WHO_V\%26B_03.07.pdf. Diakses: 28 januari 2018.

4. Widodo D., Sudoyo AW., Setiyohadi B., Alwi I. Demam Tifoid. Buku Ajar Ilmu Penyakit Dalam. 4 th ed. Jakarta: Departemen Ilmu Penyakit Dalam FKUI. 2006. 1752-57.

5. Fatmawati AR., Nahwa A., Hardian. Uji Diagnosis Tes Serologi Widal Dibandikan Dengan Kultur Darah Sebagai Baku Emas Untuk Diagosis Demam Tifoid pada Anak, Universitas Diponegoro Semarang. 2011.

6. Kulkami M., Rego S. 2007. Value of Single Widal Test in the Diagnosis of Typhoid ever. Vol 31. 2007. p. 137377. Tersedia: $13 \mathrm{http} / / / w w w . i n d i a n p e d i a t r i c s . n e t / n o v 1$ 994/1373. pdf. Diakses: 7 januari 2018.

7. Olopenia, Willke. Widal agglutination test -100 years later: still plagued by, Division of Allied Health, Howard University, Washington, DC, USA, controversy, Liberty Medical \& Research Center, Lagos, Nigeria. 2002.

8. Willke, Widal Test in Diagnosis of Typhoid Fever in Turkey, Clinical and Diagnostic Laboratory Immunology. 2002 .

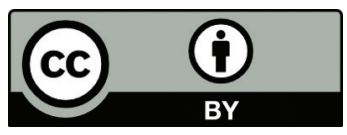

This work is licensed under a Creative Commons Attribution 